\title{
RESEARCH
}

\section{Familial associations for Addison's disease and between Addison's disease and other autoimmune diseases}

\author{
Hauke Thomsen ${ }^{101,2,3, *}$, Xinjun $\mathrm{Li}^{2, *}$, Kristina Sundquist ${ }^{2,4,5}$, Jan Sundquist ${ }^{2,4,5}$, Asta Försti ${ }^{1,2,6,7}$ and \\ Kari Hemminki ${ }^{1,2,8,9}$ \\ 1Division of Molecular Genetic Epidemiology, German Cancer Research Centre (DKFZ), Heidelberg, Germany \\ ${ }^{2}$ Center for Primary Health Care Research, Lund University, Malmö, Sweden \\ ${ }^{3}$ GeneWerk GmbH, Heidelberg, Germany \\ ${ }^{4}$ Departments of Family Medicine and Community Health, Population Health Science and Policy, Icahn School of Medicine at Mount Sinai, New York, \\ New York, USA \\ ${ }^{5}$ Center for Community-based Healthcare Research and Education (CoHRE), Department of Functional Pathology, School of Medicine, Shimane University, \\ Shimane, Japan \\ ${ }^{6}$ Hopp Children's Cancer Center (KiTZ), Heidelberg, Germany \\ ${ }^{7}$ Division of Pediatric Neurooncology, German Cancer Research Centre (DKFZ), German Cancer Consortium (DKTK), Heidelberg, Germany \\ ${ }^{8}$ Division of Cancer Epidemiology, German Cancer Research Centre (DKFZ), Heidelberg, Germany \\ ${ }^{9}$ Faculty of Medicine and Biomedical Center in Pilsen, Charles University in Prague, Pilsen, Czech Republic
}

Correspondence should be addressed to H Thomsen: hauke.thomsen@genewerk.de

${ }^{*}(\mathrm{H}$ Thomsen and $\mathrm{X}$ Li contributed equally to this work $)$

\begin{abstract}
Design: Addison's disease (AD) is a rare autoimmune disease (AID) of the adrenal cortex, present as an isolated AD or part of autoimmune polyendocrine syndromes (APSs) 1 and 2. Although AD patients present with a number of AID co-morbidities, populationbased family studies are scarce, and we aimed to carry out an unbiased study on AD and related AIDs.

Methods: We collected data on patients diagnosed with AIDs in Swedish hospitals and calculated standardized incidence ratios (SIRs) in families for concordant AD and for other AIDs, the latter as discordant relative risks.

Results: The number of AD patients was 2852, which accounted for $0.4 \%$ of all hospitalized AIDs. A total of 62 persons (3.6\%) were diagnosed with familial AD. The SIR for siblings was remarkably high, reaching 909 for singleton siblings diagnosed before age 10 years. It was 32 in those diagnosed past age 29 years and the risk for twins was 323. SIR was 9.44 for offspring of affected parents. AD was associated with 11 other AIDs, including thyroid AIDs and type 1 diabetes and some rarer AIDs such as Guillain-Barre syndrome, myasthenia gravis, polymyalgia rheumatica and Sjögren's syndrome. Conclusions: The familial risk for AD was very high implicating genetic etiology, which for juvenile siblings may be ascribed to APS-1. The adult part of sibling risk was probably contributed by recessive polygenic inheritance. AD was associated with many common AIDs; some of these were known co-morbidities in AD patients while some other appeared to more specific for a familial setting.
\end{abstract}
Key Words
- familial autoimmune disease
- adrenal cortex
- autoimmune polyendocrine syndrome
- sibling risk
- discordant risks
- polyautoimmunity

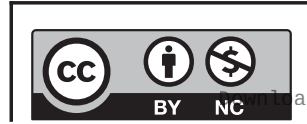

This work is licensed under a Creative Commons Attribution-NonCommercial 4.0 International License. ded from Bioscientifica.com at 04/26/2023 01:34:55PM
Endocrine Connections (2020) 9, 1114-1120 


\section{Introduction}

Addison's disease (AD) is an autoimmune disease (AID) characterized by a gradual autoantibody destruction of the adrenal cortex with resulting impaired production of corticosteroids and mineralocorticoids (1). Most patients express autoantibodies against 21-hydroxlase, an enzyme in the steroid synthetic pathway. The global prevalence is estimated as $14 / 100,000$, where $63 \%$ are women (2). The reported prevalence in Norway is also $14 / 100,000$ (3). All symptomatic patients need medical attention and the standard treatment is hormone replacement therapy, which allows most patients to remain in good health (1). AD is a common component in autoimmune polyendocrine syndrome (APS) in which multiple endocrine glands are attacked by autoantibodies $(4,5)$. $\mathrm{AD}$ is part of the rare juvenile APS-1, which is usually diagnosed before age 15 years and is caused by recessive mutations in the autoimmune regulatory gene (AIRE) $(4,5)$. The more common adult-onset APS-2 is defined through co-morbidity of at least two of the following three AIDs: $\mathrm{AD}$, type 1 diabetes or autoimmune thyroid disease, but it may also include other AIDs (4). AD patients may present with multiple AIDs, irrespective of APS-2; among Norwegian and Swedish patients only less than $40 \%$ were diagnosed with isolated $\mathrm{AD}(1,3)$. In these studies, the most common AID comorbidities were thyroid AID (in half of the patients) and type 1 diabetes (in over $10 \%$ of the patients). A family history of AD was reported in $10 \%$ of the Norwegian patients and $6 \%$ of the Swedish ones $(1,3)$. A small case-control study from Poland reported that $3 \%$ of the family members were also diagnosed with $\mathrm{AD}$ and that thyroid AID was found in almost 30\% of the family members (6). In our previous family studies, $\mathrm{AD}$ was associated with type 1 diabetes and Graves' disease in family members $(7,8)$. AD was found to be in excess after diagnosis of asthma and subsequent type 2 diabetes was increased after a diagnosis of $\mathrm{AD}(9,10)$.

$\mathrm{AD}$ (and APS-2) is a polygenic condition for which no single 'major' gene has been identified, in spite of the high twin heritability $(11,12,13)$. Twin studies have shown a high co-aggregation of AD with other AIDs, such as Hashimoto's thyroiditis, Graves' disease, celiac disease and type 1 diabetes $(12,13)$. The HLA locus was for a long time the only significant genetic risk factor for $\mathrm{AD}$, as it was for many other AIDs; the HLA DQ/DR regions regulate the antigen presentation to the T-cell receptor $(5,14)$. It was recently shown that amino acid polymorphisms within HLA class II exon 2 mediate the APS risk and differentiate between thyroid and polyglandular autoimmunity (15).
Association and sequencing studies have identified several low-risk genes which are also shared between some other AIDs (11). These include AIRE, BACH2, TTPN22, CTLA4, CLEC6A and HLA-DRB1, which jointly may account for $20 \%$ of the heritability of $\mathrm{AD}(11,16)$. These genes are relevant in many immune functions. For example, in addition to the HLA locus, AIRE encodes a protein which regulates the expression of autoantigens and negatively selects autoreactive T-cells in the thymus $(4,5)$. BACH2 maintains regulatory $\mathrm{T}$-cell function and B-cell maturation, and CTLA-4 (cytotoxic T-lymphocyte associated protein 4) acts as a major negative regulator of T-cell responses $(4,5)$. These pathways have been highlighted by the ever-increasing use of immune checkpoint inhibitors in cancer therapy. The applied monoclonal antibodies target checkpoint receptors, such as CTLA-4, and autoimmune side-effects are common $(17,18)$. In fact, some authors have suggested that the side-effects of immune checkpoint inhibitors would constitute a new type of APS (19).

Due to the sparsity of population-based family studies in $\mathrm{AD}$, we used Swedish hospital data to characterize familial clustering of concordant (between $\mathrm{AD}$ ) and discordant (AD and other AIDs). Concordant risks were assessed separately for offspring of affected parents and for siblings in order to draw conclusions about the mode of association. The discordant analysis was conducted bidirectionally: first, the relative risk was calculated for any other AID in families of $\mathrm{AD}$, followed by the relative risk for $\mathrm{AD}$ in families with other AIDs.

\section{Methods}

AID patients were identified from the Swedish Hospital Discharge Register (years 1964 through 2012, full national coverage from 1986 onwards) and the Outpatient Register (2001 through 2012). Only the first AID diagnosis was included. Of a total of 769,991 patients with any of in total 43 AIDs, 51\% were identified from the Inpatient Register and 49\% were identified from the Outpatient Register. The International Classification of Diseases (ICD) codes were used for identification of AIDs as described elsewhere (20). Family relationships were obtained from the Multigeneration Register, containing the Swedish population in families and covering parental generations for a century (21). As family members, only first-degree relatives of offspring-parent pairs and siblings were considered; 'the offspring generation' was born after 1931 and siblings could be defined only in this generation; 'the parental generation' was born any time earlier.

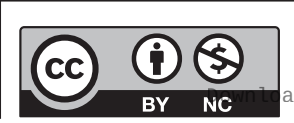

This work is licensed under a Creative Commons Attribution-NonCommercial 4.0 International License. ded from Bioscientifica.com at 04/26/2023 01:34:55PM 
By the year 2012, the offspring generation reached age 80 years. For the parental generation there was no age limit. Information from the registers was linked at the individual level via the national 10-digit civic registration number. In the linked dataset, civic registration numbers were replaced with serial numbers to ensure the integrity of all individuals. Spouses were identified through the first common child.

Standardized incidence ratios (SIRs) were calculated for the offspring generation as the ratio of observed to expected number of cases. The expected numbers were calculated for all individuals without a firstdegree family history of a specific AID and the rates were standardized by 5-year-age, gender, period (5-year groups), socioeconomic status and residential area. The 95\% CI of the SIRs were calculated assuming a Poisson distribution. Separate SIRs were calculated for offspring when only parents or only singleton siblings/twins were probands, that is, they were diagnosed with concordant AID. In the analysis of discordant AIDs, bidirectional (i.e. AD-AIDx and AIDx-AD) associations were considered. Results are shown for discordant associations if any of the comparisons were significant (95\% CI did not include 1.00).

\section{Results}

The number of $\mathrm{AD}$ patients in the offspring generation (to whom risks were calculated) was 1735 with a mean diagnostic age (i.e. first hospital contact) of 39.7 years; considering also their parents the total number was 2852 of whom $46.5 \%$ were males (Table 1). The total AID population amounted to 519,180 patients in the offspring generation of 8.5 million. Thus, $\mathrm{AD}$ accounted for $0.3 \%$ of all AIDs in the offspring generation and $0.4 \%$ in the whole population.

Table 1 Number of cases of autoimmune diseases in offspring $(n=8,517,416)$ and in the total population, 1964-2012.

\begin{tabular}{|c|c|c|c|c|c|c|}
\hline & \multicolumn{3}{|c|}{$\begin{array}{l}\text { No. of events in the } \\
\text { study population }\end{array}$} & \multicolumn{3}{|c|}{$\begin{array}{c}\text { No. of events in total of } \\
\text { population }\end{array}$} \\
\hline & No. & $\%$ & Mean age & No. & Diag. age & $\begin{array}{c}\% \\
\text { males } \\
\end{array}$ \\
\hline Total & 519,180 & & $38.8 \pm 19.5$ & 769,991 & $40.3 \pm 18.4$ & 40.2 \\
\hline $\begin{array}{l}\text { Addison's } \\
\text { disease }\end{array}$ & 1735 & 0.3 & $39.7 \pm 16.9$ & 2852 & $36.9 \pm 17.4$ & 46.5 \\
\hline $\begin{array}{l}\text { https://ec.b } \\
\text { https://doi. }\end{array}$ & $\begin{array}{l}\text { ioscientifica } \\
\text { org/10.1530 }\end{array}$ & $\begin{array}{l}\text {.com } \\
\text { /EC-20 }\end{array}$ & -0328 & & $\begin{array}{r}\text { (c) } 2020 \text { Th } \\
\text { ished by Bioscie }\end{array}$ & $\begin{array}{l}\text { e authors } \\
\text { ntifica Ltd }\end{array}$ \\
\hline
\end{tabular}

\section{Concordant familial risks}

A total of 62 persons were diagnosed with familial AD in the offspring generation, 8 with a parental and 54 with a sibling history ( 4 of the affected parental probands had remarried and were not included among the 58 individuals for 'All'). Among the total of $1735 \mathrm{AD}$ patients, 3.6\% were familial. Familial risks for AD are shown in Table 2 for offspring whose first-degree relatives (parents or siblings as probands in the top and only parents as probands in the bottom) were diagnosed with concordant disease. The overall familial risk for AD risk was 41.49 and almost identical for women and men. The risk depended on the age at diagnosis, being highest (245.54) for 0-9 year old and lowest (24.79) for those older than 29 years. The SIR was 9.44 for offspring whose parents were affected and was significant for offspring diagnosed at age 10-29 years. Of note, only 8 patients had an affected parent while 54 siblings shared the disease. We also planned to analyze the risk between spouses but no concordant couples were identified.

Risks for siblings are shown in Table 3, separating singleton siblings and twins. For singleton siblings, the SIR was 909.09 when diagnosed below age 10, and declining to 32.03 at age over 29 years. For twins, the SIR was 323.62 , the diagnostic age range was $27-67$ years. All twin pairs were of the same sex.

\section{Discordant familial risks}

We analyzed familial risks for discordant AIDs and the results are shown in Table 4 when any of the bidirectional analyses were significant; this was found for 11 other AIDs (both sexes). Both of the bidirectional SIRs were significant for 8 AIDs, including common AIDs and rarer ones, such as polymyalgia rheumatica and Sjögren's syndrome. Only one directional increases were noted for $\mathrm{AD}$ in families of rheumatoid arthritis patients, and only for Guillain-Barre syndrome and myasthenia gravis in families of AD patients. The highest risk for AD (3.44) was noted in families of type 1 diabetes. The highest risk for discordant AID in AD families was for myasthenia gravis (3.85). Of note, $43 \mathrm{AD}$ patients were found in polymyalgia rheumatic families, ranking third after families with rheumatoid arthritis (79) and Graves' disease (47). None of the sex-specific SIRs differed between men and women (i.e. the 95\% CIs overlapped). Nevertheless, only female bidirectional SIRs were increased for celiac disease and Sjögren's syndrome. Three sex-specific bidirectional SIRs were significantly increased in both sexes in associations of 
Table 2 Familial risks of Addison's disease.

\begin{tabular}{l}
$\begin{array}{l}\text { Age at diagnosis } \\
\text { (years) }\end{array}$ \\
\hline Family history \\
All \\
$0-9$ \\
$10-19$ \\
$20-29$ \\
$\geq 30$ \\
Parents only \\
All \\
$0-9$ \\
$10-19$ \\
$20-29$ \\
$\geq 30$ \\
\hline
\end{tabular}

\begin{tabular}{ll}
\hline \multicolumn{3}{c}{ Men } \\
\hline $\mathrm{O} \quad \mathrm{SIR}$ & $95 \% \mathrm{Cl}$
\end{tabular}

\begin{tabular}{lll}
\hline \multicolumn{3}{c}{ Women } \\
\hline $\mathrm{O}$ & $\mathrm{SIR}$ & $95 \% \mathrm{Cl}$ \\
\end{tabular}

\begin{tabular}{lll}
\hline \multicolumn{3}{c}{ All } \\
\hline $\mathrm{O}$ & $\mathrm{SIR}$ & $95 \% \mathrm{Cl}$ \\
\end{tabular}

Bold type: $95 \% \mathrm{Cl}$ does not include 1.00 .

$\mathrm{O}$, observed number of cases; SIR, standardized incidence ratio.

AD with type 1 diabetes, Graves' disease and Hashimoto's thyroiditis. Discordant associations are summarized in Fig. 1 for sexes combined.

\section{Discussion}

The present nation-wide study covered a rare AID, which accounted for $0.4 \%$ of all hospitalized AIDs in Sweden. Familial AD accounted for 3.6\% among all AD patients. We provided novel population-based familial risk estimates, which were very high, 41.49, and equal for men and women. Such high familial risk could be anticipated from the twin-based heritability estimates $(12,13)$. Yet they were far higher than our previous results on other AIDs. For example, concordant risk for offspring with Graves' disease with an affected parent was 4.49 (8). A surprising finding was that most familial cases $(54 / 62)$ were siblings rather than offspring of affected parents. The sibling risk was remarkably high, reaching 909 for the youngest singleton siblings but remaining as high as 32 in those diagnosed past age 29 years. The risk for twins was 323, and all but one twin were diagnosed past age 29 years. Even though all concordant twins were of the same sex, it is likely that many of them were dizygotic as reported from the Swedish Twin Register (13). In our previous studies, the concordant risk for young siblings diagnosed with type 1 diabetes was 12.3 and 8.33 for siblings diagnosed with Graves' disease at any age (7, 8). The SIRs for twins were somewhat over 20 for type 1 diabetes and 16.6 for Graves' disease.

It is likely that the early onset $\mathrm{AD}$ population consisted of APS-1, usually diagnosed before 15 years of age $(4,22)$. The syndrome is caused by recessive AIRE mutations, which is consistent with the extremely high risk between young siblings. No twins were identified at

Table 3 Familial risks of Addison's disease in siblings.

\begin{tabular}{|c|c|c|c|c|c|c|c|c|c|c|c|c|}
\hline \multirow{2}{*}{$\begin{array}{l}\text { Age at } \\
\text { diagnosis } \\
\text { (years) }\end{array}$} & \multicolumn{4}{|c|}{ Men } & \multicolumn{4}{|c|}{ Women } & \multicolumn{4}{|c|}{ All } \\
\hline & $\mathrm{O}$ & SIR & \multicolumn{2}{|c|}{$95 \% \mathrm{Cl}$} & $\mathrm{O}$ & SIR & \multicolumn{2}{|c|}{$95 \% \mathrm{Cl}$} & 0 & SIR & \multicolumn{2}{|c|}{$95 \% \mathrm{Cl}$} \\
\hline \multicolumn{13}{|l|}{$\begin{array}{l}\text { Singleton } \\
\text { siblings }\end{array}$} \\
\hline All & 25 & 82.45 & 53.30 & 121.88 & 19 & 54.08 & 32.50 & 84.62 & 44 & 67.23 & 48.83 & 90.31 \\
\hline $0-9$ & 7 & 921.05 & 365.10 & 1908.44 & 3 & 882.35 & 166.35 & 2611.88 & 10 & 909.09 & 432.94 & 1678.27 \\
\hline 10-19 & 3 & 191.08 & 36.02 & 565.63 & 2 & 192.31 & 18.13 & 707.23 & 5 & 191.57 & 60.45 & 450.63 \\
\hline $20-29$ & 8 & 178.17 & 76.10 & 352.79 & 4 & 95.69 & 24.89 & 247.44 & 12 & 138.41 & 71.17 & 242.53 \\
\hline$\geq 30$ & 7 & 29.79 & 11.81 & 61.72 & 10 & 33.82 & 16.11 & 62.43 & 17 & 32.03 & 18.62 & 51.40 \\
\hline \multicolumn{13}{|l|}{ Twins } \\
\hline All & 2 & 350.88 & 33.08 & 1290.39 & 8 & 317.46 & 135.58 & 628.59 & 10 & 323.62 & 154.12 & 597.44 \\
\hline $20-29$ & & & & & 1 & 312.50 & 0.13 & 1791.33 & 1 & 312.50 & 0.13 & 1791.33 \\
\hline $30+$ & 2 & 606.06 & 57.13 & 2228.85 & 7 & 318.18 & 126.12 & 659.28 & 9 & 355.73 & 161.28 & 678.20 \\
\hline
\end{tabular}

Bold type: $95 \% \mathrm{Cl}$ does not include 1.00 .

$\mathrm{O}$, observed number of cases; SIR, standardized incidence ratio.

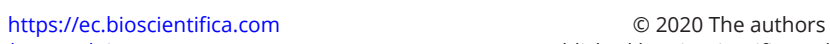
https://doi.org/10.1530/EC-20-0328

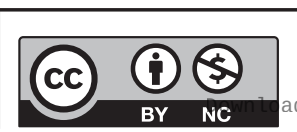

This work is licensed under a Creative Commons Attribution-NonCommercial 4.0 International License. ded from Bioscientifica.com at 04/26/2023 01:34:55PM 
Table 4 Familial risks for discordant AID.

\begin{tabular}{|c|c|c|c|c|c|c|c|c|c|c|c|c|c|}
\hline \multirow{3}{*}{$\begin{array}{l}\text { Subtypes of AID in } \\
\text { offspring } \\
\begin{array}{l}\text { Addison's } \\
\text { disease }\end{array}\end{array}$} & \multirow{3}{*}{$\begin{array}{l}\text { Family history } \\
\text { of AID } \\
\text { Celiac } \\
\text { disease }\end{array}$} & \multicolumn{4}{|c|}{ Both Genders } & \multicolumn{4}{|c|}{ Men } & \multicolumn{4}{|c|}{ Women } \\
\hline & & \multirow{2}{*}{$\begin{array}{l}\text { Obs. } \\
18\end{array}$} & \multirow{2}{*}{$\frac{\mathrm{SIR}}{1.83}$} & \multicolumn{2}{|c|}{$95 \% \mathrm{Cl}$} & \multirow{2}{*}{$\frac{\text { Obs. }}{7}$} & \multirow{2}{*}{$\frac{\mathrm{SIR}}{1.51}$} & \multicolumn{2}{|c|}{$95 \% \mathrm{Cl}$} & \multirow{2}{*}{$\frac{\text { Obs. }}{11}$} & \multirow{2}{*}{$\begin{array}{c}\mathrm{SIR} \\
2.11\end{array}$} & \multicolumn{2}{|c|}{$95 \% \mathrm{Cl}$} \\
\hline & & & & 1.08 & 2.77 & & & 0.60 & 2.84 & & & 1.05 & 3.54 \\
\hline $\begin{array}{l}\text { Celiac } \\
\text { disease }\end{array}$ & $\begin{array}{l}\text { Addison's } \\
\text { disease }\end{array}$ & 45 & 2.14 & 1.56 & 2.81 & 12 & 1.60 & 0.82 & 2.63 & 33 & 2.44 & 1.68 & 3.34 \\
\hline $\begin{array}{l}\text { Addison's } \\
\text { disease }\end{array}$ & $\begin{array}{l}\text { Diabetes mellitus } \\
\text { type I }\end{array}$ & 19 & 3.44 & 2.06 & 5.15 & 9 & 3.28 & 1.49 & 5.78 & 10 & 3.59 & 1.71 & 6.15 \\
\hline $\begin{array}{l}\text { Diabetes mellitus } \\
\text { type I }\end{array}$ & $\begin{array}{l}\text { Addison's } \\
\text { disease }\end{array}$ & 42 & 2.38 & 1.72 & 3.16 & 26 & 2.75 & 1.79 & 3.91 & 16 & 1.96 & 1.12 & 3.04 \\
\hline $\begin{array}{l}\text { Addison's } \\
\text { disease }\end{array}$ & $\begin{array}{l}\text { Graves' } \\
\text { disease }\end{array}$ & 47 & 1.76 & 1.29 & 2.29 & 20 & 1.67 & 1.02 & 2.48 & 27 & 1.83 & 1.20 & 2.58 \\
\hline $\begin{array}{l}\text { Graves' } \\
\text { disease }\end{array}$ & $\begin{array}{l}\text { Addison's } \\
\text { disease }\end{array}$ & 53 & 2.24 & 1.68 & 2.88 & 10 & 2.65 & 1.26 & 4.54 & 43 & 2.16 & 1.56 & 2.85 \\
\hline $\begin{array}{l}\text { Addison's } \\
\text { disease }\end{array}$ & $\begin{array}{l}\text { Guillain-Barre } \\
\text { syndrome }\end{array}$ & 4 & 1.97 & 0.51 & 4.37 & & & & & 4 & 3.43 & 0.89 & 7.60 \\
\hline $\begin{array}{l}\text { Guillain-Barre } \\
\text { syndrome }\end{array}$ & $\begin{array}{l}\text { Addison's } \\
\text { disease }\end{array}$ & 6 & 2.90 & 1.04 & 5.68 & 5 & 4.11 & 1.30 & 8.51 & 1 & 1.17 & 0.00 & 4.59 \\
\hline $\begin{array}{l}\text { Addison's } \\
\text { disease }\end{array}$ & $\begin{array}{l}\text { Hashimoto's } \\
\text { thyroiditis }\end{array}$ & 35 & 2.04 & 1.42 & 2.77 & 16 & 2.07 & 1.18 & 3.21 & 19 & 2.02 & 1.21 & 3.03 \\
\hline $\begin{array}{l}\text { Hashimoto's } \\
\text { thyroiditis }\end{array}$ & $\begin{array}{l}\text { Addison's } \\
\text { disease }\end{array}$ & 47 & 2.39 & 1.75 & 3.12 & 7 & 2.20 & 0.87 & 4.13 & 40 & 2.42 & 1.73 & 3.23 \\
\hline $\begin{array}{l}\text { Addison's } \\
\text { disease }\end{array}$ & $\begin{array}{l}\text { Myasthenia } \\
\text { gravis }\end{array}$ & 2 & 0.94 & 0.09 & 2.70 & & & & & 2 & 1.67 & 0.16 & 4.78 \\
\hline $\begin{array}{l}\text { Myasthenia } \\
\text { gravis }\end{array}$ & $\begin{array}{l}\text { Addison's } \\
\text { disease }\end{array}$ & 6 & 3.85 & 1.39 & 7.55 & 3 & 4.70 & 0.89 & 11.52 & 3 & 3.26 & 0.61 & 7.99 \\
\hline $\begin{array}{l}\text { Addison's } \\
\text { disease }\end{array}$ & $\begin{array}{l}\text { Polymyalgia } \\
\text { rheumatica }\end{array}$ & 43 & 2.23 & 1.61 & 2.94 & 14 & 1.73 & 0.94 & 2.76 & 29 & 2.58 & 1.73 & 3.61 \\
\hline $\begin{array}{l}\text { Polymyalgia } \\
\text { rheumatica }\end{array}$ & $\begin{array}{l}\text { Addison's } \\
\text { disease }\end{array}$ & 12 & 2.06 & 1.06 & 3.40 & 5 & 1.98 & 0.63 & 4.11 & 7 & 2.12 & 0.84 & 3.99 \\
\hline $\begin{array}{l}\text { Addison's } \\
\text { disease }\end{array}$ & $\begin{array}{l}\text { Rheumatoid } \\
\text { arthritis }\end{array}$ & 79 & 1.27 & 1.00 & 1.56 & 35 & 1.28 & 0.89 & 1.74 & 44 & 1.25 & 0.91 & 1.65 \\
\hline $\begin{array}{l}\text { Rheumatoid } \\
\text { arthritis }\end{array}$ & $\begin{array}{l}\text { Addison's } \\
\text { disease }\end{array}$ & 40 & 1.13 & 0.81 & 1.51 & 15 & 1.39 & 0.77 & 2.18 & 25 & 1.02 & 0.66 & 1.45 \\
\hline $\begin{array}{l}\text { Addison's } \\
\text { disease }\end{array}$ & Sarcoidosis & 29 & 2.57 & 1.72 & 3.59 & 11 & 2.19 & 1.09 & 3.68 & 18 & 2.87 & 1.70 & 4.35 \\
\hline Sarcoidosis & $\begin{array}{l}\text { Addison's } \\
\text { disease }\end{array}$ & 25 & 2.17 & 1.40 & 3.11 & 11 & 1.61 & 0.80 & 2.70 & 14 & 3.00 & 1.63 & 4.77 \\
\hline $\begin{array}{l}\text { Addison's } \\
\text { disease }\end{array}$ & $\begin{array}{l}\text { Sjögren's } \\
\text { syndrome }\end{array}$ & 12 & 2.09 & 1.07 & 3.44 & 4 & 1.56 & 0.41 & 3.47 & 8 & 2.51 & 1.07 & 4.55 \\
\hline $\begin{array}{l}\text { Sjögren's } \\
\text { syndrome }\end{array}$ & $\begin{array}{l}\text { Addison's } \\
\text { disease }\end{array}$ & 10 & 2.20 & 1.05 & 3.77 & 1 & 2.22 & 0.00 & 8.70 & 9 & 2.19 & 0.99 & 3.86 \\
\hline $\begin{array}{l}\text { Addison's } \\
\text { disease }\end{array}$ & $\begin{array}{l}\text { Systemic lupus } \\
\text { erythematosus }\end{array}$ & 5 & 1.06 & 0.33 & 2.19 & 3 & 1.43 & 0.27 & 3.50 & 2 & 0.76 & 0.07 & 2.18 \\
\hline $\begin{array}{l}\text { Systemic lupus } \\
\text { erythematosus }\end{array}$ & $\begin{array}{l}\text { Addison's } \\
\text { disease }\end{array}$ & 9 & 2.19 & 0.99 & 3.85 & 2 & 3.47 & 0.33 & 9.94 & 7 & 1.98 & 0.78 & 3.71 \\
\hline
\end{tabular}

Bold type: $95 \% \mathrm{Cl}$ does not include 1.00 .

$\mathrm{O}$, observed number of cases; SIR, standardized incidence ratio.

ages below 27 years, which implies that they were not APS-1 patients. The risk for singleton siblings diagnosed at age $>29$ years was 32.03 while the risk for offspring of affected parents was 9.44. The case numbers were small but the difference was significant. The common reasons for the difference in risks between siblings and offspring of affected parents are either childhood environmental sharing or recessive inheritance. In view of lacking information on strong environmental risk factors and the finding that no spouses shared an AD diagnosis, inherited factors are likely to contribute to the observed sibling risks.

Family studies on $\mathrm{AD}$ are rare and include the recent small hospital-based study from Poland and twin studies from Sweden, discussed in Introduction $(6,11,12)$. However earlier studies on other AIDs have observed significant associations with $\mathrm{AD}$ in family members, including studies on vitiligo, thyroid diseases and multiple sclerosis $(23,24,25)$. In the present study we showed significant familial associations for AD with

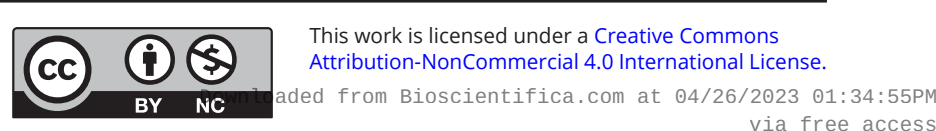




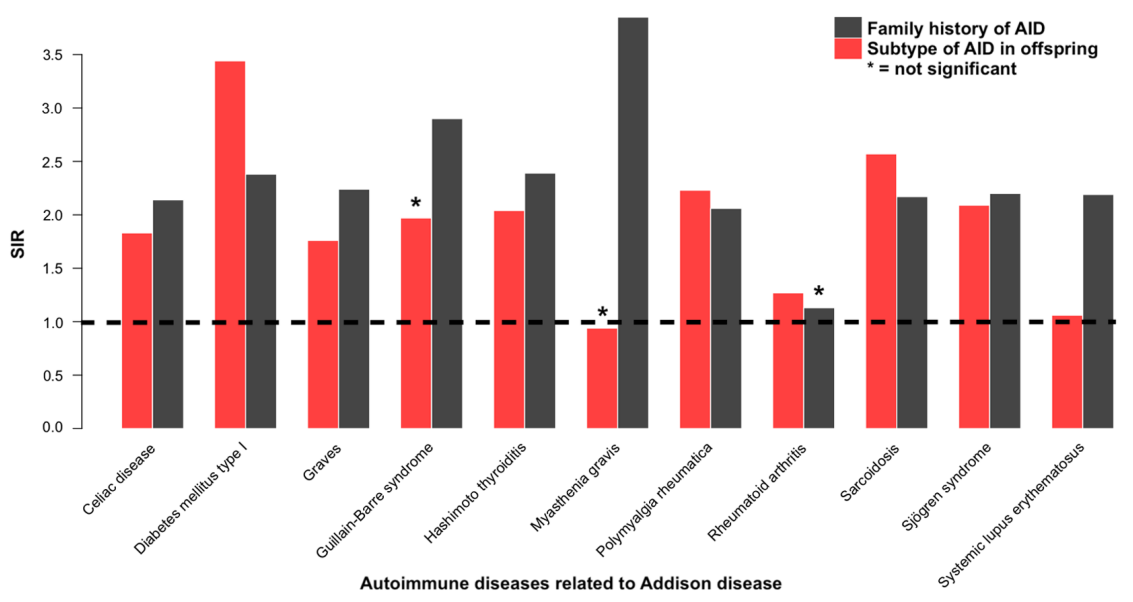

\section{Figure 1}

Bidirectional familial associations of Addison's disease (AD) with discordant autoimmune diseases (AIDs). The few associations not reaching statistical significance are shown by stars on top of the bars.
11 other AIDs, including the ones that are the most common co-morbidities in individual patients: thyroid AIDs and type 1 diabetes, and some rarer ones such as celiac disease. We had no data on some other relatively common co-morbidities, such as vitiligo or gonadal failure $(1,3)$. Pernicious anemia has been found to be a co-morbidity in Swedish patients but we found no increase in familial risk (1). Rheumatoid AIDs were clearly underrepresented among the associated AIDs, with the exception of polymyalgia rheumatic, systemic lupus erythematosus and Sjögren's syndrome. Rheumatoid arthritis is the most common AID in Swedish hospital records, and it showed a modest association (1.27) and of borderline significance only in AD families (26). Novel associations with high SIRs were found for Guillain-Barre syndrome, myasthenia gravis, polymyalgia rheumatica and Sjögren's syndrome. The genetic link between $\mathrm{AD}$ and myasthenia gravis and polymyalgia rheumatica may be the HLA locus $(27,28)$. Co-morbidity of AD and myasthenia gravis has previously been reported (29).

Limitations of the present study include the low patient numbers because of the rarity of $\mathrm{AD}$ and many comparisons, whereby some of the results may yield chance findings. The design of applying bidirectional analysis will in part alleviate the problem of multiple comparisons, as parent-offspring pairs are independent in the bidirectional analysis. Thus significant results in the bidirectional analyses, as was the case for most observed associations, provide support for 'true' associations. The strengths of the study were diagnostics in a standard way in a highlevel health care system, accessible to the population at large without economic barriers. The family relationships were obtained from the Swedish Multigeneration Register with unbiased and complete family relationships (21).

In summary, we found a very high familial risk for $\mathrm{AD}$, particularly among siblings. The juvenile component of the risk could be ascribed to ASP-1. The adult component of sibling risk was probably contributed to by polygenic inheritance. AD was associated with many common AIDs, some of which were known co-morbidities in AD patients. Significant familial associations were also found for rare AIDs, such as Guillain-Barre syndrome, myasthenia gravis, polymyalgia rheumatica and Sjögren's syndrome.

\section{Declaration of interest}

The authors declare that there is no conflict of interest that could be perceived as prejudicing the impartiality of the research reported.

\section{Funding}

The study was supported by the European Union's Horizon 2020 research and innovation program, grant no. 856620 .

\section{Ethics}

The guidelines of the Helsinki Declaration were followed. The study was approved by the Regional Ethical Review Board in Lund.

\section{Author contribution statement}

$\mathrm{KH}, \mathrm{H}$ T and $\mathrm{X} L$ contributed to design. J $\mathrm{S}$ and $\mathrm{K} \mathrm{S}$ involved in acquisition of data. X L, H T and K H involved in statistical analysis and interpretation. $\mathrm{KH}$ and A F involved in manuscript writing. All authors involved in the approval of the final text.

\section{References}

1 Dalin F, Nordling Eriksson G, Dahlqvist P, Hallgren A, Wahlberg J, Ekwall O, Söderberg S, Rönnelid J, Olcén P, Winqvist O, et al. Clinical and immunological characteristics of autoimmune Addison disease: a nationwide Swedish multicenter study. Journal of Clinical Endocrinology and Metabolism 2017102 379-389. (https://doi. org/10.1210/jc.2016-2522)

2 Hayter SM \& Cook MC. Updated assessment of the prevalence, spectrum and case definition of autoimmune disease. 
Autoimmunity Reviews 201211 754-765. (https://doi.org/10.1016/j. autrev.2012.02.001)

3 Erichsen MM, Løvås K, Skinningsrud B, Wolff AB, Undlien DE, Svartberg J, Fougner KJ, Berg TJ, Bollerslev J, Mella B, et al. Clinical, immunological, and genetic features of autoimmune primary adrenal insufficiency: observations from a Norwegian registry. Journal of Clinical Endocrinology and Metabolism 200994 4882-4890. (https:// doi.org/10.1210/jc.2009-1368)

4 Husebye ES, Anderson MS \& Kämpe O. Autoimmune polyendocrine syndromes. New England Journal of Medicine 2018378 1132-1141. (https://doi.org/10.1056/NEJMra1713301)

5 Kahaly GJ \& Frommer L. Autoimmune polyglandular diseases. Best Practice and Research: Clinical Endocrinology and Metabolism 201933 101344. (https://doi.org/10.1016/j.beem.2019.101344)

6 Fichna M, Małecki PP, Młodzikowska M, Gębarski B, Ruchała M \& Fichna P. Increased risk of endocrine autoimmunity in first-degree relatives of patients with autoimmune Addison's disease. European Journal of Endocrinology 2020183 73-81. (https://doi.org/10.1530/ EJE-20-0150)

7 Hemminki K, Li X, Sundquist J \& Sundquist K. Familial association between type 1 diabetes and other autoimmune and related diseases. Diabetologia 200952 1820-1828. (https://doi.org/10.1007/s00125009-1427-3)

8 Hemminki K, Li X, Sundquist J \& Sundquist K. The epidemiology of Graves' disease: evidence of a genetic and an environmental contribution. Journal of Autoimmunity 201034 J307-J313. (https:// doi.org/10.1016/j.jaut.2009.11.019)

9 Hemminki K, Li X, Sundquist J \& Sundquist K. Risk of asthma and autoimmune diseases and related conditions in patients hospitalized for obesity. Annals of Medicine 201244 289-295. (https://doi.org/10.3 109/07853890.2010.547515)

10 Hemminki K, Liu X, Försti A, Sundquist J, Sundquist K \& Ji J. Subsequent Type 2 diabetes in patients with autoimmune disease. Scientific Reports 20155 13871. (https://doi.org/10.1038/srep13871)

11 Eriksson D, Bianchi M, Landegren N, Dalin F, Skov J, HultinRosenberg L, Mathioudaki A, Nordin J, Hallgren Å, Andersson G, et al. Common genetic variation in the autoimmune regulator (AIRE) locus is associated with autoimmune Addison's disease in Sweden. Scientific Reports 20188 8395. (https://doi.org/10.1038/s41598-01826842-2)

12 Skov J, Eriksson D, Kuja-Halkola R, Höijer J, Gudbjörnsdottir S, Svensson AM, Magnusson PKE, Ludvigsson JF, Kämpe O \& Bensing S. Co-aggregation and heritability of organ-specific autoimmunity: a population-based twin study. European Journal of Endocrinology 2020 182 473-480. (https://doi.org/10.1530/EJE-20-0049)

13 Skov J, Höijer J, Magnusson PKE, Ludvigsson JF, Kämpe O \& Bensing S. Heritability of Addison's disease and prevalence of associated autoimmunity in a cohort of 112,100 Swedish twins. Endocrine 2017 58 521-527. (https://doi.org/10.1007/s12020-017-1441-z)

14 Mitchell AL \& Pearce SH. Autoimmune Addison disease: pathophysiology and genetic complexity. Nature Reviews: Endocrinology 20128 306-316. (https://doi.org/10.1038/nrendo.2011.245)

15 Frommer L, Flesch BK, König J \& Kahaly GJ. Amino acid polymorphisms in hla class II differentiate between thyroid and polyglandular autoimmunity. Journal of Clinical Endocrinology and Metabolism 2020105 1737-1747. (https://doi.org/10.1210/clinem/dgz164)

16 Skinningsrud B, Lie BA, Lavant E, Carlson JA, Erlich H, Akselsen HE, Gervin $\mathrm{K}$, Wolff $\mathrm{AB}$, Erichsen MM, Løvås $\mathrm{K}$, et al. Multiple loci in the HLA complex are associated with Addison's disease. Journal of Clinical
Endocrinology and Metabolism 201196 E1703-E1708. (https://doi. org/10.1210/jc.2011-0645)

17 de Filette J, Andreescu CE, Cools F, Bravenboer B \& Velkeniers B. A systematic review and meta-analysis of endocrine-related adverse events associated with immune checkpoint inhibitors. Hormone and Metabolic Research 201951 145-156. (https://doi. org/10.1055/a-0843-3366)

18 Zhai Y, Ye X, Hu F, Xu J, Guo X, Zhuang Y \& He J. Endocrine toxicity of immune checkpoint inhibitors: a real-world study leveraging US Food and Drug Administration adverse events reporting system. Journal for ImmunoTherapy of Cancer 20197 286. (https://doi. org/10.1186/s40425-019-0754-2)

19 Sperling M \& Yau M. Autoimmune polyglandular syndromes. In Endotext. Eds KR Feingold, B Anawalt, A Boyce, et al. South Dartmouth, MA, USA: MDText.com, Inc., 2020. (available at: https:// pubmed.ncbi.nlm.nih.gov/25905375/)

20 Hemminki K, Forsti A, Sundquist K, Sundquist J \& Li X. Familial associations of monoclonal gammopathy of unknown significance with autoimmune diseases. Leukemia 201630 1766-1769. (https:// doi.org/10.1038/leu.2016.43)

21 Hemminki K, Ji J, Brandt A, Mousavi SM \& Sundquist J. The Swedish Family-Cancer Database 2009: prospects for histology-specific and immigrant studies. International Journal of Cancer 2010126 2259-2267. (https://doi.org/10.1002/ijc.24795)

22 Kahaly GJ \& Hansen MP. Type 1 diabetes associated autoimmunity. Autoimmunity Reviews 201615 644-648. (https://doi.org/10.1016/j. autrev.2016.02.017)

23 Boelaert K, Newby PR, Simmonds MJ, Holder RL, Carr-Smith JD, Heward JM, Manji N, Allahabadia A, Armitage M, Chatterjee KV, et al. Prevalence and relative risk of other autoimmune diseases in subjects with autoimmune thyroid disease. American Journal of Medicine 2010123 183.e1-183.e9. (https://doi.org/10.1016/j. amjmed.2009.06.030)

24 Laberge G, Mailloux CM, Gowan K, Holland P, Bennett DC, Fain PR \& Spritz RA. Early disease onset and increased risk of other autoimmune diseases in familial generalized vitiligo. Pigment Cell Research 200518 300-305. (https://doi.org/10.1111/j.16000749.2005.00242.x)

25 Nielsen NM, Frisch M, Rostgaard K, Wohlfahrt J, Hjalgrim H, KochHenriksen N, Melbye M \& Westergaard T. Autoimmune diseases in patients with multiple sclerosis and their first-degree relatives: a nationwide cohort study in Denmark. Multiple Sclerosis $2008 \mathbf{1 4}$ 823-829. (https://doi.org/10.1177/1352458508088936)

26 Hemminki K, Li X, Sundquist J \& Sundquist K. Familial associations of rheumatoid arthritis with autoimmune disorders and related conditions. Arthritis and Rheumatism 200960 661-668. (https://doi. org/10.1002/art.24328)

27 Varade J, Wang N, Lim CK, Zhang T, Zhang Y, Liu X, Piehl F, Matell R, Cao H, Xu X, et al. Novel genetic loci associated HLA$\mathrm{B}^{*} 08: 01$ positive myasthenia gravis. Journal of Autoimmunity $2018 \mathbf{8 8}$ 43-49. (https://doi.org/10.1016/j.jaut.2017.10.002)

28 González-Gay MA, Matteson EL \& Castañeda S. Polymyalgia rheumatica. Lancet 2017390 1700-1712. (https://doi.org/10.1016/ S0140-6736(17)31825-1)

29 Fang F, Sveinsson O, Thormar G, Granqvist M, Askling J, Lundberg IE, Ye W, Hammarström L, Pirskanen R \& Piehl F. The autoimmune spectrum of myasthenia gravis: a Swedish populationbased study. Journal of Internal Medicine 2015277 594-604. (https:// doi.org/10.1111/joim.12310)

Received in final form 6 October 2020

Accepted 8 October 2020

Accepted Manuscript published online 8 October 2020 https://ec.bioscientifica.com https://doi.org/10.1530/EC-20-0328 (c) 2020 The authors Published by Bioscientifica Ltd

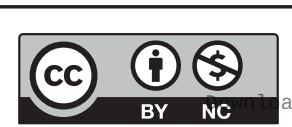

This work is licensed under a Creative Commons Attribution-NonCommercial 4.0 International License. ded from Bioscientifica com at 04/26/2023 01:34:55PM 